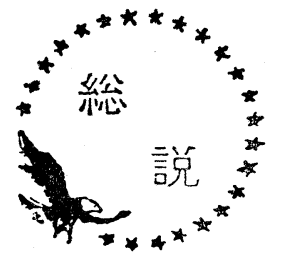

1.はじめに

エネルギー資源としての天然ガスの価值は, 近年急 速に増大している。日本に抢いては, LNG (液化天然 ガス）として輸入する天然ガスが，大気污染，水污染 の全くない公害に関して理想的なエネルギー資源とし て取り上げられつつある。

エネルギー資源として輸入する LNG は最終的には ガス状で燃料として消費される。通常の場合は LNG の大部分が受入基地で気化され，パイプラインによつ て需要家まで送られる。液状で取り扱われるものは, パイプラインの完成していない需要家に供給する場合 だけであろら。

気化装置として一般に考えられているものは, 海水 を熱源とするもの，天然ガスを燃焼させて熱源とする ものなど種々の方式があるが，いずれにしても費用を かけて蒸発させるものであり, その費用は, 輸入天然 ガスの価格の $2 \sim 3 \%$ にも達している。天然ガスは, 液化基地で莫大な動力を消費して液化されたものであ るので，このきわめて価值のある LNG の冷熱は，捨

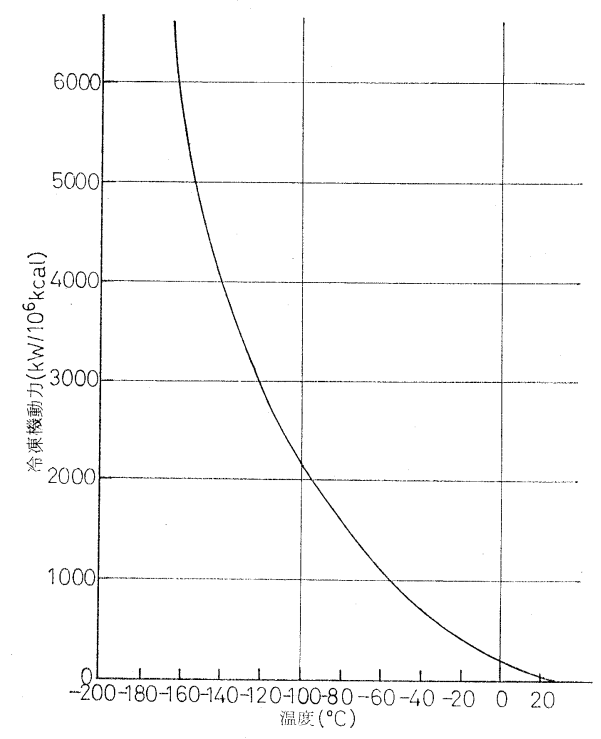

図 1 冷熱 の 利用
日本揮発油株式会社 星協一

て去るものでなく，積極的に利用すべきものである う。

冷熱の利用方法としては，種々のものが考えられて いる。たとえば海水淡水化プラント，アンモニア合成 プラント, 液酸液窒製造プラント, 石油化学などへの 利用がある。実際に行なわれているものは，東京瓦斯 根岸工場の LNG を利用している液酸液窒製造プラン トである。その他, LNG 中の重質分を分離するのに 自身の冷熱を利用しているイタリアの La Spezia 基地 などがある。ここでは石油化学に利用したものについ て考えてみよう。

\section{2. 冷熱の価値}

冷熱注通常コンプレッサーを使用して発生させる。 熱の除去泠却水を使用するので, 水温は $20 \sim 30^{\circ} \mathrm{C}$ である。したがっで，冷熱の価值はコンプレッサーの 消費動力で表わすことができる。使用冷媒やコンプレ ッサーの効率で多少の差があるが, 温度と消費動力の 関係を図1のように図示することができる。この図で 明らかなように冷熱の価值は温度が低いと急激に増加 することがわかる。

LNG の温度は最低 $-162^{\circ} \mathrm{C}$ であり, 気化圧力に よって利用できる泠熱の量と温度は異なつてくる。ま た 極低温で LNG の温度以下の泠熱が必要なときで も，LNG 学冷却源として冷凍コンプレッサーを使用 すれば，消費動力はきわめて少なくてすむ。しかし， $-162^{\circ} \mathrm{C}$ またはそれ以下のような極低温の冷熱を大量 に必要とする石油化学プロセスは少ない。図1でも明 らかなように， $-100^{\circ} \mathrm{C}$ 以下になると冷熱を発生させ るに必要な動力は急激に増加するので, このような温 度で操作するプロセスが成立しなかつたのであろう。

\section{L N G の冷熱}

LNG の利用できる泠熱の温度と量の関倸は，LNG の気化圧力に影響されることは前でも触れたがその実 際注図 2 のようである。LNG を純メタンと仮定し，メ タンの Pressure-enthalpy diagram をわかりやすいよ らに書き直したものである。圧力は常圧, $10 \mathrm{~kg} / \mathrm{cm}^{2} \mathrm{~g}$, $70 \mathrm{~kg} / \mathrm{cm}^{2} \mathrm{~g}$ の 者を選んだ。 $70 \mathrm{~kg} / \mathrm{cm}^{2} \mathrm{~g}$ 洁 Critical 


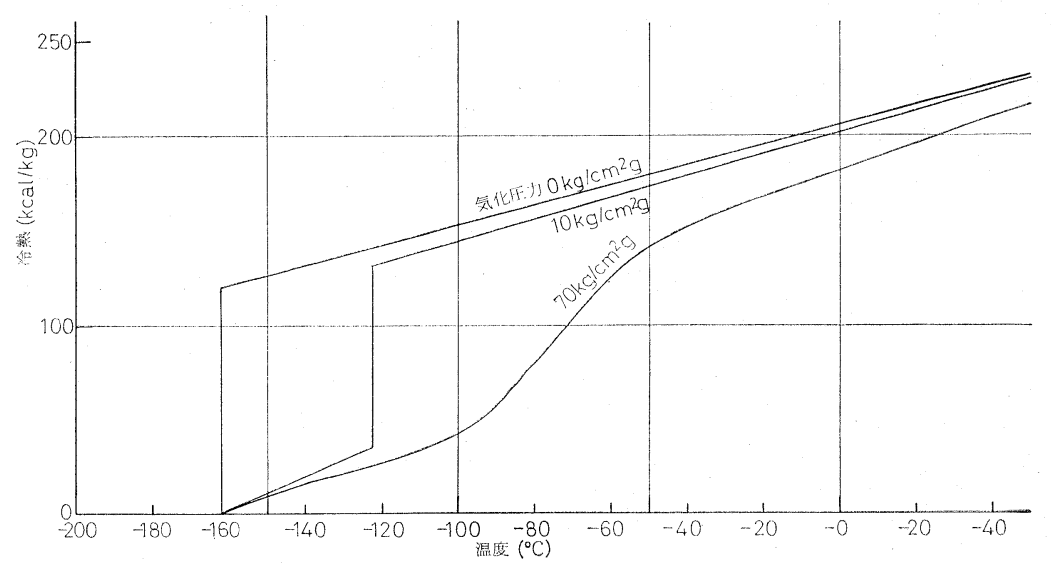

図 2 L N G（メタン）の冷熱

\section{表 1 L N G の冷熱の価值}

気化後の圧力を $10 \mathrm{~kg} / \mathrm{cm}^{2} \mathrm{~g}$ とする。 気化量を $10,000 \mathrm{~kg} / \mathrm{hr}$ とする。

r
気

pressure 以上であるので蒸発を示す温度一定の区域 がない。

泠熱の発生に必要とする冷凍機のコンプレッサーの 動力より気化したメタンを圧縮する動力の方が少ない ので，低い温度の冷熱を必要とするならば，必要温度 の圧力で蒸発させ，気化したガスを圧縮することがよ い。これを数字で示したものが表 1 である。LNG を 気化させて $10 \mathrm{~kg} / \mathrm{cm}^{2} \mathrm{~g}$ のガスを必要とする場合に, 常圧で蒸発させコンプレッサーで圧縮する価值と， $10 \mathrm{~kg} / \mathrm{cm}^{2} \mathrm{~g}$ まで液体で加圧し蒸発させる冷熱の価值を 比較した。冷熱の価值は, 図 1 によつて動力で表わ し，これよりコンプレッサーの動力またはポンプの動 力を減じて LNG の泠熱の評価を示した。ここで示し た冷熱は, 蒸発温度までの冷熱である。すなおち常圧 の場合は $-162^{\circ} \mathrm{C}$ の蒸発潜熱であり $10 \mathrm{~kg} / \mathrm{cm}^{2} \mathrm{~g}$ の場 合は $-162^{\circ} \mathrm{C}$ から $-122^{\circ} \mathrm{C}$ までの液の顕熱と $-122^{\circ} \mathrm{C}$ の蒸発潜熱を加えたものである。後者の場合の冷熱の
評価は $-122^{\circ} \mathrm{C}$ の動力で行なつてある。

\section{4. 石油化学への応用}

\section{4-1 LNG 冷熱利用の実際}

LNGの大量輸送はまだ始まつたばかりで，LNGの 冷熱を利用した石油化学プロセスを本格的に採用する 時期ではないようである。実際に採用されている冷熱 の利用は, LNG に含まれている重質分を蒸留で分離 するプロセスに LNG 自身の泠熱を使用しているもの である。スペインの Barcelona 基地, イタリアの La Spezia 基地でリビヤから輸入した LNG より重質分 を分離するのに使用されている。リビヤの LNG の組 成は表 2 に示すよらに, かなり重質分を含んでいる LNG である。

重質分を分離する主な目的は, 気化後の天然ガスの 発熱量を一定にするためである。イタリアでは, 全国 的なパイプライン網に送り込まれるので, 他の天然ガ スと発熱量索一致させる必要がある。イタリアでは分 


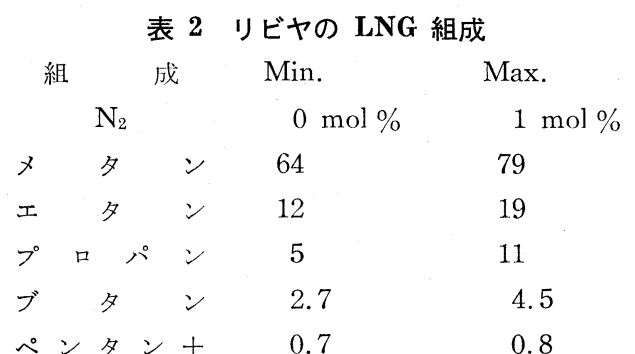

離した重質物はリフォーミングで低発熱量のガスにし て希釈するのに用いられる。

一例としてイタリヤの La Spezia 基地における重 質分分離のフローダイヤグラムを図 3 に示す。このフ ローは LNG-2 の報文1) その他で発表されているもの である。LNG Tankよりポンプで 圧送された LNG は熱交換により加熱されて Flash drum に入り主と してメタンを分離, つぎに Deethanizer でエタンを分

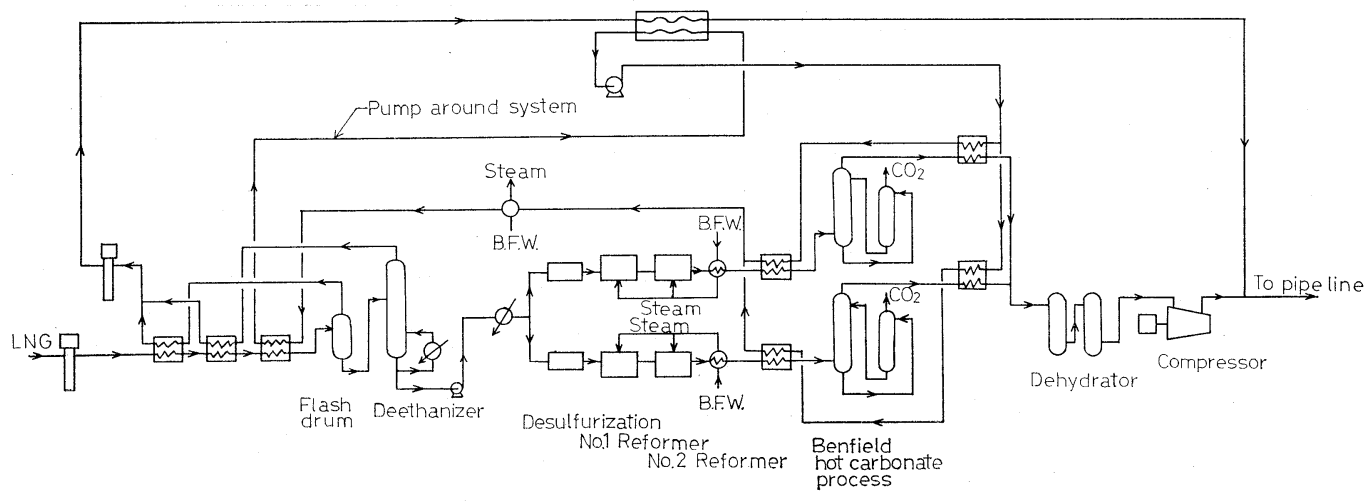

図 3 La Spezia LNG 基地フローダイヤグラム

離する。メタンおよびエタンのコンデンサーの冷源と して, 送入される LNGの冷熱が利用されている。こ のプロセスの冷熱の利用には二つの目的がある。一つ は Deethanizer に対する還流に使用するコンデンサー の冷源であり，もう一つは，パイプラインの圧力が55 〜 $70 \mathrm{~kg} / \mathrm{cm}^{2} \mathrm{~g}$ であるので, メタンおよびエタンをガス で圧縮するより, 液状で昇圧させるための全凝縮用の 冷源である。塔頂で部分凝縮させて残つたガスをコン プレッサーで圧縮するより，全凝縮の液体をポンプで 昇圧させた後に再び気化させるほうが, 動力の面から も，建設費の面からも有利だからである。ただしこの 方法は冷熱の有効利用の面から見ると 3 項で説明した ように, 有利な方法ではないが，その他に冷熱を利用 するところがない La Spezia 基地ではよい方法であ ろら。

その他にこのプラントでは, Pump around system と称して Deethanizer の塔底液すなわちプロパンを主 成分とする 熱媒体を循環させて 熱回収を行なつてい る。55 70 kg/ $\mathrm{cm}^{2} \mathrm{~g}$ の LNG の気化の冷熱をリフォ 一ムドガスの冷却, 脱炭酸後の泠却に使用している。

4-2 文献などに見られる石油化学への応用

(1) LNG-12) で Air product が，重質分を含む LNG を原料にするエチレン製造について提案してい る。表 3 に示されるようなアルジェリアの LNG より

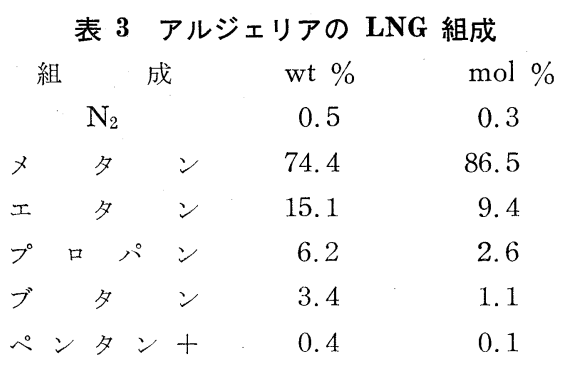

エタンを分離してエチレンの原料としている。エタン はエチレンの原料としては最適なものである。ナフサ 分解によるエチレン製造はエチレンの収率が $30 \%$ 程度 であるのに対して, エタン分解によるものは, エタン のリサイクルを行なつて $80 \%$ 以上の収率が得られる。 報文では，エタン分解によるエチレンの高収率を強調 しているが, ナフサ分解による製品は, 日本ではエチ レン以外も重要なものであるので簡単には比較できな い。しかし目的によつてはエタンは原料として有利な ものである。エタンを原料とするエチレン装置は, ナ フサ分解のものに比較すると装置は小型で簡単なもの になるのである。

報文では，エチレン製造の原料としての重質分を分 離するフローダイヤグラムとして図 4 を示している。 分離についての考え方は, 分離は一定流量で処理し, 


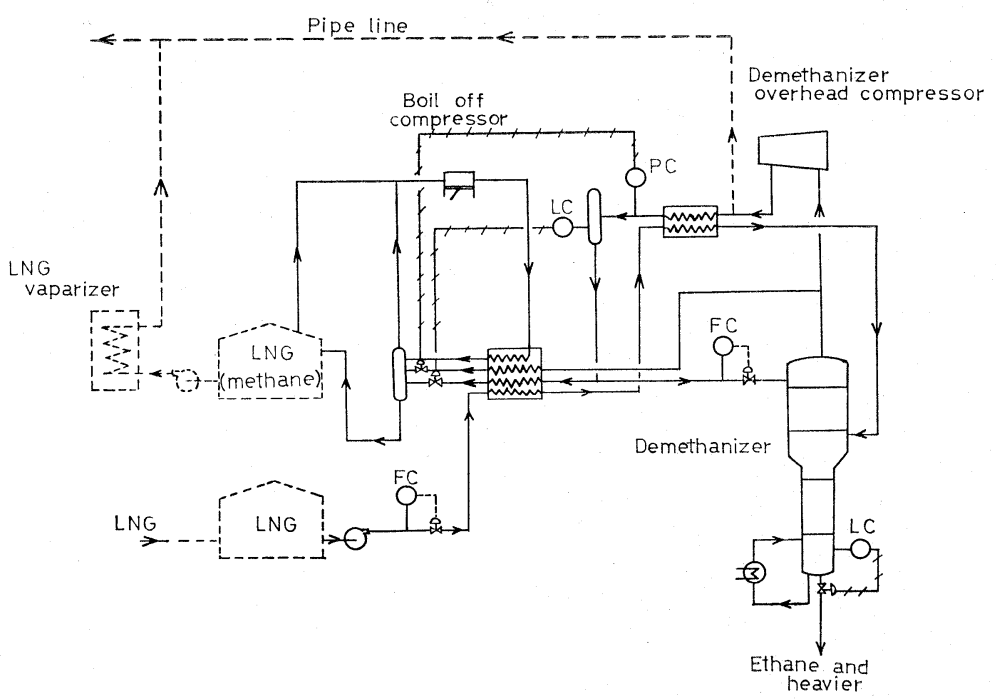

図 4 LNG プラントよりエタンおよび重質分の回収

軽質分は最小の要求量のみガス状で送り出し, 大部分 は液化して貯蔵し，Peak load に対応させるようにし ている。

Demethanizer でメタンを蒸留で分離し，塔頂より のメタンはコンプレッサーで圧縮した後, 原料の LNG の冷熱によつて凝縮, タンクに貯蔵される。

アルジェリアの LNG では, $2.85 \times 10^{6} \mathrm{Nm}^{3}$ /日 $(800,000 t /$ 年) の原料より, $85,000 t /$ 年のエチレンが 得られる。この文献で, エチレン装置で必要な冷熱は 全部 LNG の冷熱でまかならようにしてエチレンの洒 格を試算している。ナフ少分解 450, 000t/年のエチレ ン $25.17 £ / \mathrm{t}(25.4 ¥ / \mathrm{kg})$ に対してLNGよりのエ タンを使用し， $\mathrm{LNG}$ の冷熱を利用したものについて $16.85 £ / \mathrm{t} \sim 20.12 £ / \mathrm{t}(17.0 ¥ / \mathrm{kg} \sim 20.3 ¥ / \mathrm{kg})$ とし
ている。LNG 利用の価格に範囲があるのは，分離し たプロパン，ブタンをそれぞれの価格で評価した場合 が安価な場合で, 燃料で評価すればエタンの価格があ がり, エチレンも高価になるのである。

(2) 特許に見られる LNG の冷熱の利用

LNG は新しい分野であるので，その冷熱の利用の 方法も特許で公示されるものもある。

(a) 低圧下の液状天然ガスから高圧下のメタンに富 むガスの製造法といら名称で Air liquid より出され た特許3がある。重質分を含む LNGより重質分を除 き高圧のメタンガスを作るプロセスである。目的とし ては，前に述べた La Spezia 基地で行なわれている プロセスおよび LNG-1 の文献で見られるものと同じ ものである。図 5 (A) が特許に記載されたフローダ

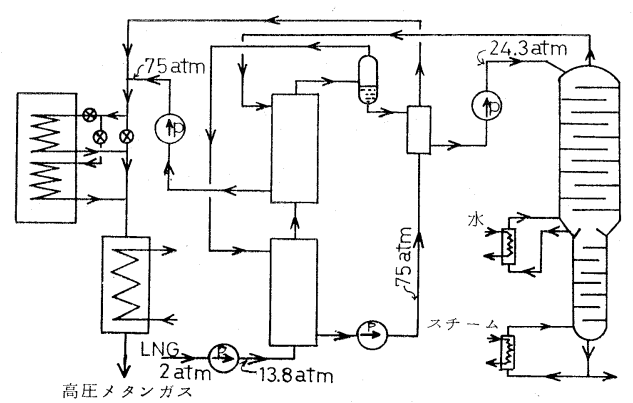

(A)

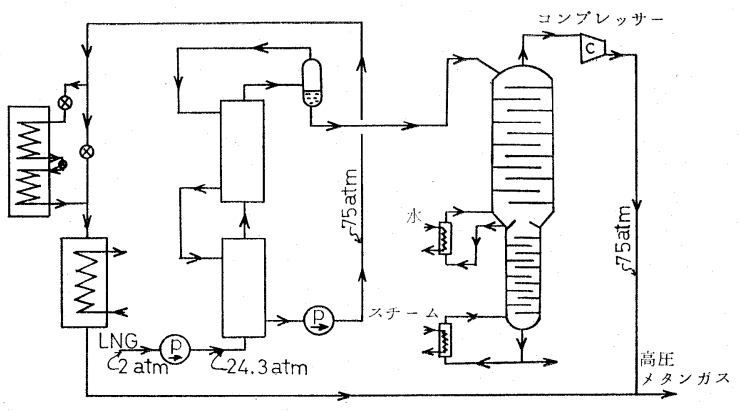

(B)

図 5 低圧下の LNG から高圧下のメタンに富むガスの製造法 
イヤグラムである。13.8atm のフラッシュドラムと， 24.3atm の Demethanizer を持つている。フラッシュ ドラムで分離したメタンは, LNG の䫓熱の冷熱によ つて凝縮する。凝縮メタンはポンプで75atm まで昇圧 される。フラッシュドラムに残つた液はポンプで昇圧 Demethanizer で蒸留される。Demethanizerよりの メタンは, $13.8 \mathrm{~atm}$ の LNG の潜熱にようて凝縮す る。13.8 atm で一部蒸発した LNG はフラッシュド ラムに送られ，一方の凝縮メタンはポンプで $75 \mathrm{~atm}$ で界圧, フラッシュドラムで分離液化されたメタンと 合流，適当な熱源によつて気化されて高圧メタンとな る。

フラッシュドラムの圧力と蒸留塔の 操作圧を変え て, 蒸留塔の蒸気はフラッシュドラム送入 LNG の蒸 発の潜熱で㠜縮させている。一方フラッシュドラムよ りの蒸気は送入 LNG の顕熱で凝縮させている。LNG の温度が常圧の沸点で供給されることを利用したもの である。特許では表 4 のような原料, 製品の場合,
表 4 LNG より高圧メタンガスの製造法

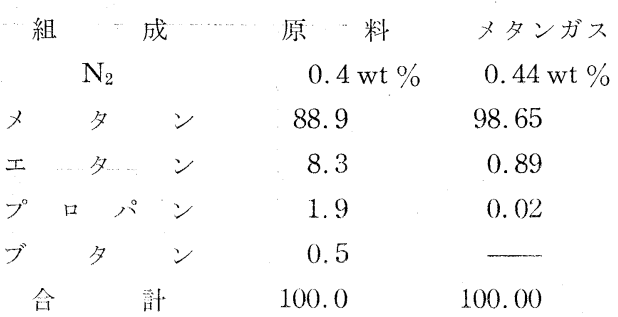

$\mathrm{LNG}$ の送人量が $302,376 \mathrm{l} / \mathrm{hr}$ ( $\div 100$ 万 t/年) の時 に図 5 (B) の通常の方法, 寸なおち Demethanizer よりの蒸気をコンプレッサーを使用して圧縮した場合 の動力と比較している。これによるとコンプレッサー を使用すると約 1,700 1, 800kW 動力が増加する。

(b) 同じく特許に LNG の玲熱を石油精製のテール ガスの分離に使用したプロセスがある。ガス状炭化水 素類の分離方法 ${ }^{4)}$, 製油所テールガスの分離法5) とい 万名称で Conch Methane Service より出されてい

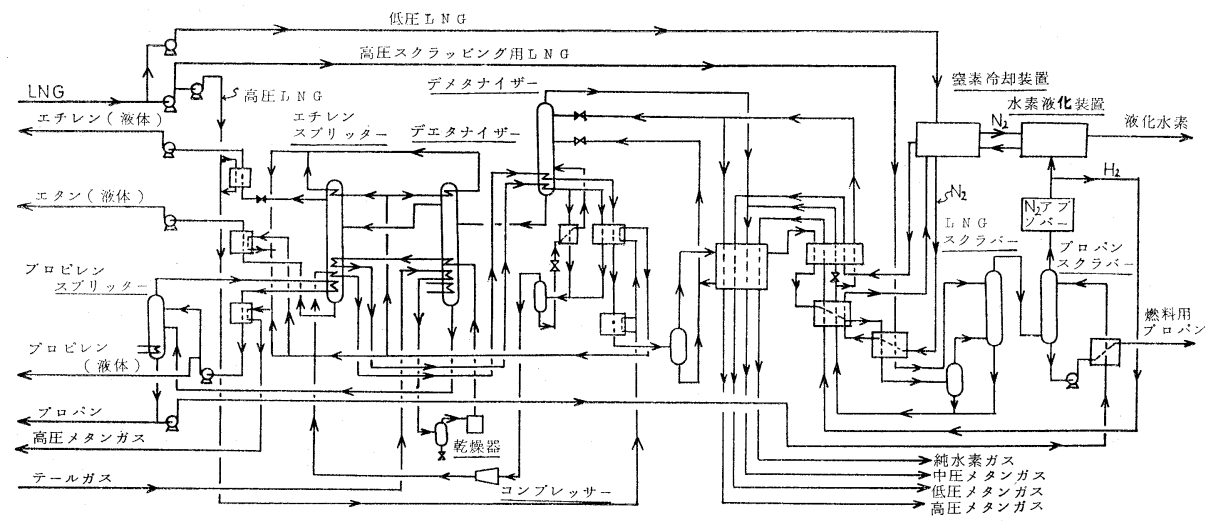

図 6 製油所テールガス分離のフローダイヤグラム

\begin{tabular}{|c|c|}
\hline 表 5 製 & $=$ ールガス \\
\hline 成 & テールガス \\
\hline $\mathrm{H}_{2}$ & $20 \mathrm{~mol} \%$ \\
\hline $\mathrm{CO}, \mathrm{N}_{2}$ & 5 \\
\hline 夕 & 40 \\
\hline F $V$ & 5 \\
\hline タ & 15 \\
\hline ME & 5 \\
\hline 1220 & 9.5 \\
\hline 類 & 0.5 \\
\hline 計 & 100 \\
\hline
\end{tabular}

る。このプロセスはとくに目新しいものではないが石 油精製のテールガスの分離と LNG の冷熱とをたくみ
に組合せてある（図 6)。

石油精製のテールガスとしては, 表5のものを代表 的な原料組成として説明している。製品として, 高純 度の水素, エチレン, エタン, プロピレン, プロパ ン, 高沸点分に分離される。分離されたメタンは, 気 化した LNG と混合されて燃料ガスとなる。燃料ガス は利用した冷熱の温度に応じて低圧 $\left(1.05 \mathrm{~kg} / \mathrm{cm}^{2} \mathrm{abs}\right)$

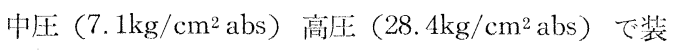
置より出ていく。

このプロヒスは大きく分けて分離装置, 空素冷却装 置, 水素液化装置の三つの部分より成立つている。石 油精製のテールガスは分離装置でおのおのの製品に分 離される。分離装置は, Demethanizer, Deethanizer, 
Ethylene splitter, Propylene splitter の蒸留塔と, テールガスの乾燥器, テールガスのコンプレッサーが 主な機器である。また, 水素ガスの精製部門として, LNG スクラバー，プロパンスクラバーがある。

原料の精油所のテールガスは, $10.5 \mathrm{~kg} / \mathrm{cm}^{2} \mathrm{abs}$ で Deethanizer のリボイラーに入り, 熱源として熱をあ たえる。ここで $10^{\circ} \mathrm{C}$ を泠却され, 重質分を凝縮分離 する。ついで乾燥器で永分が除去され, Deethanizer reboiler, Ethylene splitter reboiler, Demethanizer reboiler の熱源に使用され, さらにLNG で $-85^{\circ} \mathrm{C}$ まで冷却される。 $-85^{\circ} \mathrm{C}$ まで冷却されて重質分は凝縮 する。液体は Demethanizer に送られ，ガスはコンプ レッサーで $30.6 \mathrm{~kg} / \mathrm{cm}^{2}$ abs まで圧縮される。压縮後 ふたたび Deethanizer reboiler, Demethanizer reboiler の熱源に使用して冷却され，LNG でさらに $-95^{\circ} \mathrm{C}$ まで冷却される。凝縮したメタンは Demethanizer に送られる。ガスはさらにLNGおよび液体品 溸で $-180^{\circ} \mathrm{C}$ まで冷却, さらに凝縮液とガスに分離さ れる。凝縮液は，レフラックスとして Demethanizer の塔頂八送入される。ガスは不純物を含む水素である が, LNG スクラバーで液体窒素で冷却された LNG によってスクラッビングされて主に $\mathrm{CO}, \mathrm{N}_{2}$ が除去 され，約 $99 \%$ の水素になる。この水素はさらに同じく 液体空素で冷却されたプロパンによつてスクラッビン グされてメタンが除去され，約 $99.8 \% の \mathrm{~N}_{2}$ を不純物 とする水素ガスとなる。この水素ガスは窒素アブソ一 バ-一゙不純物の最後の痕跡が除去される。純水素は, 一部はガス状で冷熱を回収した後製品として送り出さ れ, 一部は水素液化装置で液体窒素で泠却されて液体 水素となる。スクラッビングに使用し， $\mathrm{CO}, \mathrm{N}_{2}$ を吸 収した LNG，メタンを吸収したプロパンは再生する ことなくそのまま燃料として送り出される。燃料とし て使用する場合は吸収した不純分を含んでいてもさし つかえな。

Demethanizer では塔頂よりメタン，塔底より重質 物が得られる。重質物は Deethanizer, Ethylene splitter, Propylene splitter で蒸留されて, エタン, エチレン, プロピレン, LPG の製品を得ている。

LNG の利用は, 高圧の LNG として, 製油所テー ルガスの冷却, Deethanizer の Condenser, Ethylene splitter $の$ Condenser, Propylene splitter $の$ Condenser の冷熱源および製品エチレン，エタンの泠却 の泠熱源に利用される。高圧 LNG の一部は, 常压の 沸点以下の 温度 $\left(-180^{\circ} \mathrm{C}\right)$ まで泠却されて LNG の スクラバーの洗滌液に使用される。洗滌液は一部を
Demethanizer のリフラックスに使用し，残りは冷熱 回収後, 燃料ガスとして送り出される。塔頂よりのガ スは凝縮させることなく冷熱を回収して中圧燃料ガス として送り出される。

低圧の LNG は低い温度を必要とする窒素冷却装置 で蒸発し，冷熱をあたえて常圧に近い燃料ガスとして 外部に出る。

窒素冷却装置は液体窒素を冷媒とする冷凍機であ る。冷却源に低圧の LNG を利用し, コンプレッサー を使用して液体穻素を作り, 水素液化装置および水素 分離精製部門の冷熱として循環している。

この説明のよらに, LNG の泠熱を利用して精油所 のテールガスをおの拉のの成分に分離している。とく に水素の精製に冷 LNG, 冷プロパンを使用して不糊 物をスクラッビングし，使用した LNG，プロパンは 再生することなくそのまま蒸発して燃料ガスとして送 り出していることが特徴であろら。また, 水素の分離 精製の冷却に液体空素昰使用することも特徵であろ ら。このテールガスはリボイラーの熱源として利用す るためと, 水素分離精製のために高圧に圧絔されてい るが, Demethanizer などの蒸留塔の 操作圧は普通の 場合に比較して低い。冷熱としてLNG 利用してい るので低くできるのである。

4-3 エチレン製造装置への㐫用

エチレン製造装置の冷凍機は，天然ガスの液化に使 用されている冷凍機と並んで工業用に使用されている ものの中では大型のものである。大量に得られるLNG の冷熱の利用として，エチレン製造装置はまず考えら れるものであろら。

エチレン製造装置の概略を説明する。日本に扮ける

\section{衰 6 エチレン製造ナフサ分解ガス組成}

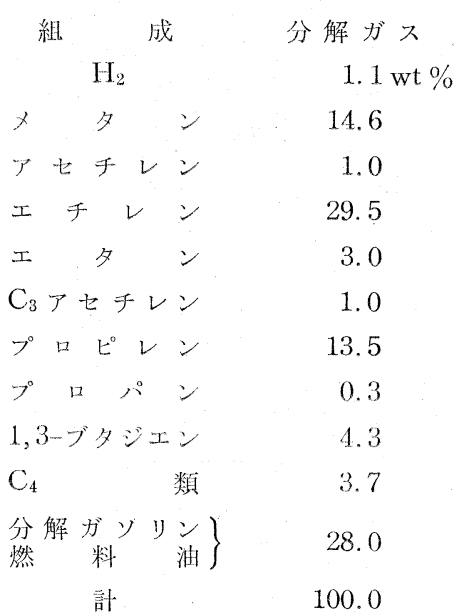




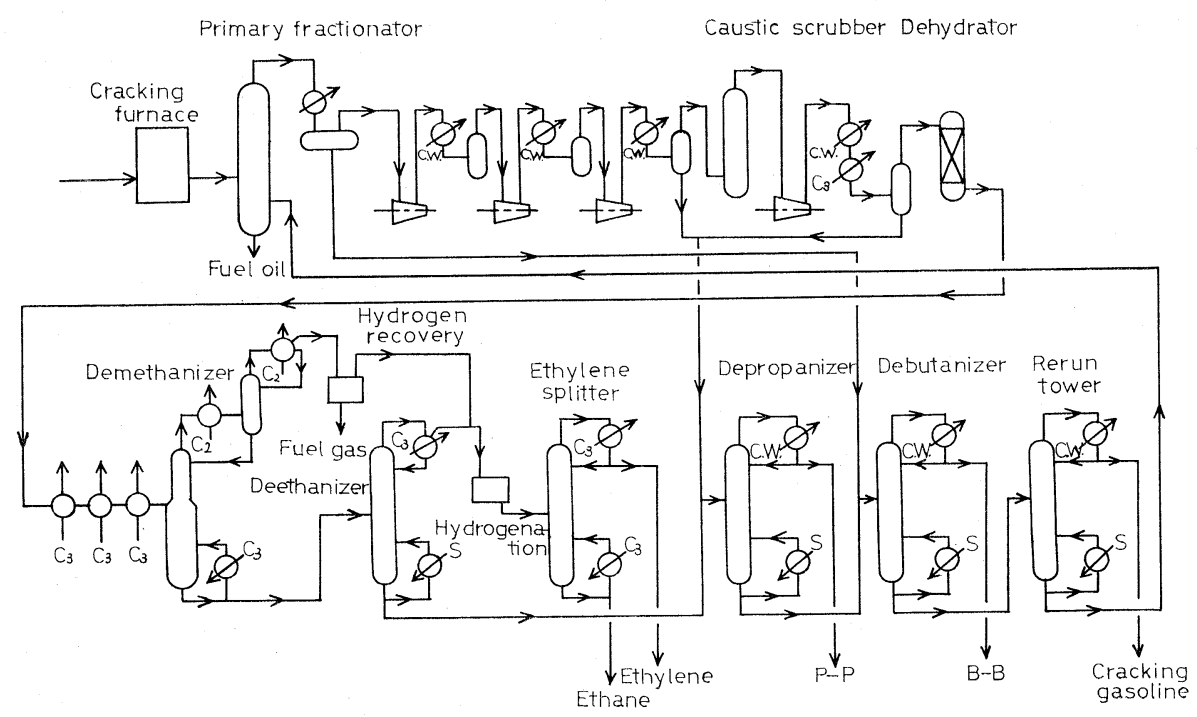

図 7 エチレン製造装置

エチレン製造は大部分がナフサ分解によるものであ る。ナフサを管式の分解炉でスチームの存在下で熱分 解してエチレンを含む分解ガスを得る。その組成 ${ }^{6)}$ の 一例を表 6 に示す。

分解ガスは, Primary fractionatior で蒸留, 分解ガ ソリンの一部および然料油を分離する。重い留分を分 離した分解ガスはコンプレッサーー゙約 $35 \mathrm{~kg} / \mathrm{cm}^{2} \mathrm{~g}$ ま で圧縮し, 冷却して Demethanizer に送入される。途 中, 圧力の上昇抢よび泠却によつて分解ガソリン, $\mathrm{C}_{4}$ 類, $\mathrm{C}_{3}$ 類の一部は分離される。圧縮の途中でカ性ソ ーダなどにて洗涤して脱硫および乾燥剤にて乾燥され る。Demethanizer の Feed は, プロピレン冷凍で冷 却される。Demethanizer のレフラックスコンデンサ 一およびインターナルコンデンサーはエチレン冷凍が 使用され，リボイラーはプロピレン冷媒の凝縮により 加熱される。Demethanizer の塔頂よりは, 水素およ びメタンが得られる。一部の水素はメタンのジュール トムソン効果によつて冷却されてメタンを分離して濃 縮される。Demethanizer の塔底は, Deethanizer に 送られて塔頂よりエチレン, エタンを, 塔底に $\mathrm{C}_{3}$ 類 より重いものを残す。エチレン, エタンは, 水添によ つてこれらに含まれて来るアセチレン分をエチレンに 転換した後, Ethylene splitter で塔頂にエチレン，塔 底にエタンを分離する。この蒸留は, コンデンサーは プロピレン冷媒で泠却し, リボイラーはプロピレン冷 媒の凝縮により加熱される。Deethanizer の塔底物は,
コンプレッサー中間段の凝縮物と合わさつて Depropanizer で $\mathrm{C}_{3}$ 類を塔頂に, $\mathrm{C}_{4}$ 類より重質物を塔底に 分離される。この Depropanizer はコンデンサーにプ ロピレン冷凍を使用するケースもある。Depropanizer 以降の分離には冷凍は使用しない。Debutanizer で $\mathrm{C}_{4}$ 類を, Rerun tower で分解ガソリンを分離する。以 上のよらに，エチレン製造装置では，Demethanizer， Deethanizer, Ethylene splitter, 回りに冷凍機が使用 される。その他エチレン, プロピレンの製品を常圧冷 凍貯蔵するための冷却にも使用される。

エチレン製造装置の冷凍機は, プロピレンを冷媒と する冷凍機とエチレンを冷媒とする冷凍機を持つてい

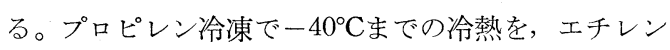
冷凍で $-101^{\circ} \mathrm{C}$ までの冷熱を得ている。この冷凍用コ ンプレッサーの動力は, 最近のナフサ分解による 30 万 $\mathrm{t} /$ 年のもので, プロセスに使用されるものだけで 22, $000 \sim 25,00 \mathrm{~kW}$ でである。

(1) エチレン製造装置の全冷凍を LNG の泠熱で使 用することを考えて見る。30万 $\mathrm{t} /$ 年のもので直接プ ロセスを冷却している冷熱はプロピレン冷凍で約 25.9 $\times 10^{6} \mathrm{kcal} / \mathrm{hr}$, エチレン冷凍で約 $3.8 \times 10^{6} \mathrm{kcal} / \mathrm{hr}$ で ある。冷凍コンプレッサーは多段であり, 中間段よ り蒸気を吸引させて中間の温度の泠熱も使用してい る。この冷熱を全部 LNG の冷熱で置き換えるのであ る。

LNG は $-162^{\circ} \mathrm{C}$ から $10^{\circ} \mathrm{C}$ までの冷熱を使用する 
ものとし，気化圧力を $70 \mathrm{~kg} / \mathrm{cm}^{2} \mathrm{~g}$ とする。図 2 の LNG の冷熱の $70 \mathrm{~kg} / \mathrm{cm}^{2} \mathrm{~g}$ の線によつて冷熱を使用 することになる。利用できる冷熱は $188 \mathrm{kcal} / \mathrm{kg}$ であ り必要とする冷熱は $29.7 \times 10^{6} \mathrm{kcal} / \mathrm{hr}$ であるから，

$$
\frac{29.7 \times 10^{6}}{188}=158,000 \mathrm{~kg} / \mathrm{hr}
$$

となりこの量は年間にすると 138.4 万 $\mathrm{t}$ である。こ の計算だけでなく図 2 の LNG の泠熱の曲線と, プロ セスが各温度で必要とする泠熱の量を比較して, 各温 度における熱収支をチェックすることが必要である。 詳細は省略するが，上記の LNG の量はこの関係を満 足している。

LNG 138 万 $\mathrm{t} /$ 年の 気化量は現在の輸入量に比較す れば非常に大きな量であり，この量の天然ガスを長期 間連続して使用する安定需要が必要条件である。

この LNG の冷熱の利用は現在の冷凍機を使用した エチレン装置の冷熱をそのまま LNG の冷熱で置き換 えたものとして試算した。先に述べたテールガスの分 離のように， LNG の低い温度の泠熱を利用するエチ レン製造装置のプロセスを組むことが有効利用の上か ら必要がある。

（2）つぎに温度の低い LNG の冷熱を利用するエチ レン製造装置を考えてみよう。LNG の気化量とエチ レンの生産量との組合わせで種々のものが考えられる が，エチレンの生産量は現在の情勢からして 30 万 $\mathrm{t} /$ 年程度であろう。LNG の気化量としては, あまり大 きい量では実際的ではないので, エチレン冷谏のみを 置き換えることにして試算する。また，LNG の泠熱 温度はエチレン冷凍より温度が低いので, この温度に 適するように蒸留塔の操作圧を下げることを考えた。
LNG の気化圧力は $10 \mathrm{~kg} / \mathrm{cm}^{2} \mathrm{~g}$ として低い温度で利用 することとした。分解ガスはナフサを原料とするエチ レン含有量が $27 \sim 30 \mathrm{wt} \%$ のハイシビヤリティのも のである。

このよらな条件で考光たプロセスフローダイヤグラ ム図 8 である。エチレン冷凍は Demethanizer 回りの みで使用されるので，この部分のみを示した。その他 は普通のものと同じである。

エチレン冷凍は最低温度が $-101^{\circ} \mathrm{C}$ であり LNG は $-162^{\circ} \mathrm{C}$ であるので, Demethanizer の操作压を温度 に対応するまで下げることができる。普通の場合は $35 \mathrm{~kg} / \mathrm{cm}^{2} \mathrm{~g}$ であるが，これが $17 \sim 18 \mathrm{~kg} / \mathrm{cm}^{2} \mathrm{~g}$ にな る。

LNG はまず最も低い温度の泠熱を必要とする Demethanizer condenser に送入される。このコンデン サーでは LNG の顕熱が利用される。次に Internal condenser で泠熱を与える。ここでは顕熱と一部の蒸 発の潜熱が利用される。 LNG の $10 \mathrm{~kg} / \mathrm{cm}^{2} \mathrm{~g}$ の蒸発 温度は $-122^{\circ} \mathrm{C}$ である。LNG は再に気液混層で Demethanizer final feed chiller に送られ冷熱を与える。 この泠却は潜熱およびガスの顕熱で行なわれる。これ より前段の Feed chiller での熱交は天然ガスを常温 近くまで加温するためである。温度はプロピレン冷凍 の温度であるので LNG の泠熱でプロセスの泠却が不 足する分はプロピレン冷凍で補うことになる。天然ガ

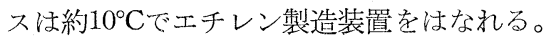

このフローで水素回収部での水素純度は普通の場合 より操作圧が低いのでやや悪くなるが，アセチレン水 添用の水素としては充分である。純度を高くしたい場

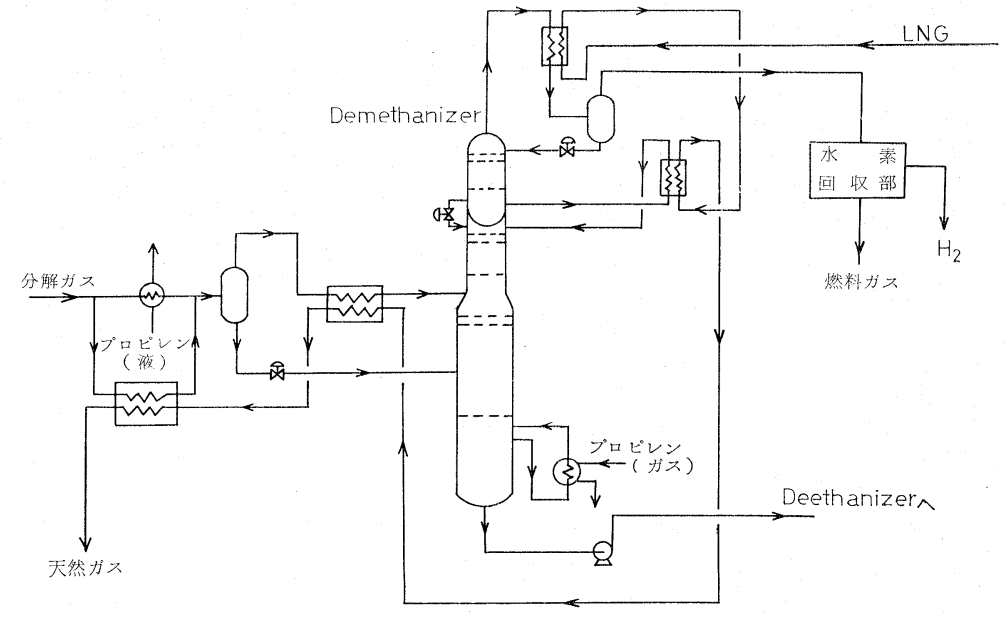

図 8 エチレン製造装置 (LNG 利用) 
表 7 エチレン製造装置のユーティリティ

(30万 $\mathrm{t} /$ 年)

動 力

分解ガスコンプレッサー

プロピレン冷凍コンプレッサー

エチレン冷涷コンプレッサー

合

部
普通

$19,800 \mathrm{~kW}$

19,200

3,400

42,400
LNG 利用

$16,700 \mathrm{~kW}$

13,200

0

29,900
$12,500 \mathrm{~kW}$ 減

冷 却 水 $3,000 \mathrm{t} / \mathrm{hr}$ 減
合は，コンプレッサーで圧縮して LNG の冷熱を利用 すれば容易に行なうことができる。

このフローのようにLNG を利用したときの冷熱の 評価について考えてみよら。ユーティリティの減少は 表 7 のよである。エチレン冷凍用コンプレッサーの 動力だけでなく, エチレン泠媒の泠却用のプロピレン 冷凍コンプレッサーの動力の減少, さらに Demethanizer の操作圧の 低下による分解ガスコンプレッサー の動力の減少がある。必要とする LNG は 35.5 万 t/ 年の割合である。エチレンの処理量の 30 万 $\mathrm{t} /$ 年 は 330 日稼動して算出した。LNG は 365 日で 35.5 万 t であり，330日で実際に使用されるものは 32 万 t であ る。

LNG の気化量 35.5 万 $\mathrm{t} /$ 年 は現在考えられてい尚 LNG 基地の規模からして Base load として連続した 安定需要が期待できる数值であるう。

この LNG 利用による総運転費の減少を試算する と, 動力減少として, $1 \mathrm{KWhr}$ 当り 3 円と評価すれば 3 円 $\times 12,500=37,500$ 円 $/ \mathrm{hr}$

冷却水を $1 \mathrm{t}$ 当たり 2 円とすれば 2 円 $\times 3,000=6,000$ 円 $/ \mathrm{hr}$

合計して 43,500 円/ hr 330 日稼動として $344,520,000$ 円/年

建設費はエチレン冷凍機の省略, プロピレン冷凍機の 縮少, 分解ガスコンプレッサーの圧縮段数の減少など により $5 \sim 6$ 億円減少する。金利, 償却, メンテナン スなどの装置コストを毎年建設費の $30 \%$ と考えると $550,000,000$ 円 $\times 0.3=165,000,000$ 円 総運転費の減少として, ユーティリティ減少と装置コ ストを合計して

$$
509,520,000 円 / \text { 年 }
$$

エチレン生産量当たりに換算すると

$$
\text { 1.70円/エチレンkg }
$$

LNG 気化量当たりに換算すると 1.59 P/LNG kg

この LNG 気化量当たりの冷熱の評価は, エチレン 冷凍を省略, Demethanizer の操作圧を低下させて LNGを利用したときのものである。

\section{LNG 冷熱の評価}

冷熱の価值は前に述べたようにその温度に対圭する 動力で表わ的ことができる。したがつて温度が決まれ ば冷熱は評価できることになる。このように考えれば 気化圧力によつて LNG の評価は，一定になるはずで ある。しかし実際には LNG が与えることのできるよ らな低温を必要とするプロセスは非常に少ない。高い 温度でよい泠熱に低い温度のものより与えれば, その 冷熱の価值は高い温度のもので評価される。

. LNG の冷熱を石油化学を含めて種々のものに利用 した例についてその評価が計算されているが，もつと 马低温で利用している液体酸素, 液体窒素製造用に利 用したものが評価が高くなつている。一例としてLNG 当たりに換算すると 2.64 円/LNG kg が発表されて いる。

そのつぎに評価のよいものが，前項のエチレン製造 であろう。その他のものについては利用温度が高いの で評価も低くなつている。

試算してはいないが，前に述べた特許の例で水素の 精製に LNG を利用したり，水素の液化の冷源にLNG を利用することによって，その評価は液酸液窒と同等 かそれ以上のものになるであろら。

しかし LNG 冷熱の単位重量当たりの評価が高くて も, LNG の冷熱を利用して最終的に生産されたもの の需要が少なければその評価は計算上だけのものにな つてしまう。LNG の冷熱は利用先がなくても水やガ スに与えて捨てるものであるから単位重量当たりの評 価だけで比較するものでなく，利用した絶対量で比較 
するものかもしれない。エチレン製造に利用する場合 も，LNG が安定して大量に利用できるようになつた ときは, 単位重量当たりの評価は減少寸るぶ, プロピ レン冷凍, エチレン冷凍の全部を $\mathrm{LNG}$ の冷熱で置き 換える方法がよいのではないか。

天然ガスの液化を別とすればエチレン製造装置に使 用されている冷凍機は非常に大きいもので，このよう な多量の冷熱を消費するプラントは他にない。LNG の冷熱もこの量に対応できるものである。30万 $\mathrm{t} /$ 年 のエチレン製造で全冷熱を LNGから得るとしても LNG 138 万 $\mathrm{t} /$ 年のものである。現在 LNG の輸入も 1,000 万 $\mathrm{t} /$ 年の単位の輸入基地を検討されようとして いるときであるので，もつと大量の冷熱を利用するプ ラントを考えねばならないであるら。

\section{LNG の冷熱利用の問題点}

LNG の 冷熱をエチレン製造に利用することは, LNG の消費の広い範囲で可能である。そしてその LNG の利用によりメリットは考えられる。しかしこ こで大きな問題点となるのは LNG の安定供給の点で ある。30万t/年のエチレン製造装置は，それだけで も 100 億円を超える装置でありそれに関連するコンビ ナート全体の投資金額は非常に巨大なものである。こ の巨大な装置群を LNG の供給に合おせて運転するこ とはできない。エチレン製造装置はエチレンその他の 製品の需要に合わせて運転することが最優先である。

また，エチレン製造装置を LNG の冷熱，冷凍機の 泠熱の画者とも使用するよらにすると，建設費がどら らか一方の専用機より増大寸るので，メリットは減少 する。LNG の温度に合せて操作圧を決定して設計し た装置では，冷凍機で運転することはできない。 このような理由でエチレン製造装置に合わせた LNG の連続した供給が絶対の条件になる。安定供給の量と 年間の輸入量との割合は天然ガスの用途によつて異な ると思うが，絶対に宏定連続に供給できる量となると 小さい割合になると思う。
一方 LNG の需要者にとつてもエチレン製造装置の 運軽に合わせて消費を変えることも困るし, 装置の事 故で天然ガスの供給が停止されることがあつてはなら ないであろら。また装置のメンテナンスも当然考えら れる。このため建設費の安価な気化装置たとえばサブ マージトバーナー型のようなものを予備気化器として 持つことが必要である。予備器は運転時間が短いので 運転費より建設費を優先させたもので差支えない。こ のような気化器は割合に安価であるので問題なく受入 れられるであろう。

LNG の輸入, LNG と石油化学コンビナートの組 合わせは非常に大きい危険性を持つた企業である。現 在の LNG の輸入は原油などの場合と異なり, 液化基 地 $\rightarrow \mathrm{LNG}$ タンカーい受入基地が一組になつた形態を とつている。日本の場合は，これに外国との関係を含 んだものになつている。政治的なものを含めてどこか 一ケ所に事故が起こつた場合に LNG の輸入が停止す ることが考えられる。LNG と石油化学コンビナート が組合わされることになると，LNG の確実な輸入の 保証がないと実行できないものになるのではないか。

複数の液化基地より多数の LNG タンカーが輸送す るように LNG の使用が一般化され，大規模の LNG 基地が建設されるようになれば LNG 中断の危険性は 急速に小さくなるので LNG の冷熱を利用した石油化 学コンビナートも自然に計画されるようになるである 50

\section{文献}

1) Paper, Proceeding 2nd International Conference on LNG, Paris 1970

2) Paper, Proceeding 1st International Conference on LNG, Chicago 1968

3) 特許公報, 昭 $45-31855$

4）特許公報, 昭45-30082

5）特許公報, 昭45-31441

6) U.S.A. Patent, 1, 165, 906 


\title{
Utilization of LNG Cold Energy in the Petrochemical Industry
}

\author{
by Kyoichi Hoshi \\ (Japan Gasoline Co., Ltd.)
}

SYNOPSIS:-Depending on its mode of use, LNG possesses great value as a source of cold energy. The application of the cold energy of LNG to the petrochemical industry is explained hereunder.

Facilities actually constructed and in operation which utilize the cold energy of LNG to separate the heavy components contained in the LNG are those at the Barcelona Terminal in Spain and the La Spezia Terminal in Italy.

A method of using the cold energy of LNG for separation purposes and for the ethylene production unit itself, wherely ethane separated from LNG containing heavy components in used as feed for ethylene production, is described in the literature released by Air Products Ltd. in "LNG-1".

There is a process, in the patent stage, by which heavy components are separated from LNG containing such comporents and high-pressure methane gas is produced. This method does not require the use of the compressor for which a patent application has been lodged by Air Liquid.

The methane is liquefied using the cold energy of LNG and vaporized after being pressurized with a pump.

Similarly, Conch Methane Service has announced its patented method which utilizes the cold energy of LNG to separate refinery tail-gas into its individual components.

A scrubbing method using LNG and propane chilled by means of liquefied nitrogen to remove trace quantities of impurities from hydrogen, is adopted.

The use of the cold energy of LNG in an ethylene production plant, taking the case of an ethylene production rate of 300,000 tons per year, is described briefly.

In this case, 1,380,000 tons per year of LNG will be required if all necessary refrigeration is to be carried out by the sole use of LNG.

Trial calculations were per formed on the basis of using LNG for the ethylene refrigeration around the demethanizer only. These calculations evaluate the cost of one kilogram of LNG at 1.59 yen.

The use of the cold energy of LNG, especially in ethylene production units, will probably be realized with the establishment of stable supply and increased imports of LNG. 